\title{
HPV-vaksinen ti år - hva er status?
}

\author{
Den første kreftforebyggende vaksinen ble møtt med begeistring og skepsis. Nobelprisen for det grunnleg- \\ gende arbeidet kom raskt. Mange spørsmål ble stilt, og de fleste er i dag avklart - med et positivt resultat.
}

Vaksinen mot humant papillomavirus (HPV) har vært tilgjengelig i ti år (1). Det gir grunn til refleksjon. Egentlig begynte det for alvor ett år tidligere: Den første fase III-studien hadde behandlingstrengende celleforandringer (CIN 2+) som endepunkt (2). Da den forhåndsdefinerte interimstudien viste at alle tilfellene forårsaket av HPV-16 og -18 var i placebogruppen, anbefalte den eksterne data- $\mathrm{og}$ sikkerhetskomiteen at studien måtte avbrytes av etiske grunner: En fortsettelse ville forsinke vaksinasjonen av placebogruppen. Godkjenningen som fulgte, gikk i USA som «fast track», og European Medicines Agency (EMA) fulgte raskt opp. Dermed ble den også godkjent i Norge.

Da startet den norske debatten, heftig og bredt anlagt - til manges forundring $\mathrm{i}$ innog utland. Ingen tidligere vaksiner var nemlig blitt så grundig utprøvd, med mer enn 70000 deltagere. Vaksinemotstand er velkjent. Det nye nå var imidlertid at den kom fra uventet hold. Tidsskriftet ledet tidlig an med en serie kritisk lederartikler, påpekte flere ubesvarte spørsmål og manet til utsettelse til vi visste mer (3-5). VG førte an med krigsoverskrifter som 20 døde - HPVvaksinen kan bli innført $i$ Norge. Riktignok sto det i selve artikkelen at ingen av dødsfallene skyldtes vaksinen. Og slik fortsatte det. Bioteknologinemda stilte seg kritisk to år etter at beslutningen om å innføre vaksinen var tatt, og ble refset av helsedirektøren for å komme sent på banen (6).

\section{Kostnad-nytte-vurderinger}

Kunnskapssenterets første vurdering var basert på enkeltdose apotekpris pluss moms. Momsen var nøytral på statens hånd, men apotekprisen var kunstig høy i studiene fordi det ikke ble tatt hensyn til de store rabattene, opptil 50-80\% som gis ved å kjøpe mange doser til nasjonale vaksineprogrammer. Tross dette var regnestykket fortsatt positivt.

Konsekvenser som redusert risiko for konisering og derved for prematuritet og senaborter, kreft andre steder og sykdom hos menn, i tillegg til betydning for fremtidig screening, har i ingen eller begrenset grad vært inkludert (7).

Når vi vet at kostnadene kan reduseres ytterligere fordi det er tilstrekkelig med bare to doser, blir et fordelaktig regnestykke ytterligere forbedret (8). Det åpner for at også gutter kan tilbys vaksinasjon. I land med velfungerende screeningprogrammer ser man nå mer humant papillomavirus forårsake orofaryngeal kreft hos menn enn cervixcancer. Den første er økende, den andre avtagende. Derfor er potensialet for kreftprofylakse fremover minst like stort hos menn (9).

\section{Vaksineeffekt}

Man har i liten grad debattert vaksineeffekt, bortsett fra valg av endepunkt. Siden CIN $2+$ er en obligat prekursor for cervixcancer, ble det av helsemyndighetene og Verdens helseorganisasjon (WHO) bestemt å måtte være studieendepunkt $(10,11)$. Ikke å behandle slike lesjoner for å vente på kreft er klart

\section{«Mye av denne forsk- ningen kommer fra Norge og Norden, fordi ingen kan gjøre det bedre!»}

uetisk, men likevel ble slike studier etterlyst. At en studie med observasjon av forstadienes betydning allerede var publisert fra New Zealand - og med katastrofalt resultat - var lite kjent: En tredel av deltagerne som ble observert, fikk invasiv cervixcancer. Enda verre var det at de ikke visste at de deltok $i$ en studie (10).

Varigheten av vaksineeffekten kunne man selvfølgelig ikke vite initialt, men basert på langtidsoppfølging ti år etter avsluttede studier (totalt 13 år) viser den ingen svikt. Mye av denne forskningen kommer fra Norge og Norden, fordi ingen kan gjøre det bedre! En vanlig myte er at det er for sent med vaksine etter seksuell debut. Det er god klinisk dokumentasjon for kvinner opptil 45 år (12).

HPV-infeksjonen er vanligvis intracellulær og intraepitelial med lite cellenekrose og derfor lite immunogen. Både residiv, reinfeksjon og reaktivering er vanlig og ses særlig hos hivpositive pasienter og andre immunsupprimerte. Det gjelder også store grupper med pasienter som får immunsupprimerende behandling. Ved slike tilstander kan det ha særlig verdi å vaksinere før terapistart $(13,14)$.

En av bekymringene var om man kunne oppleve oppblomstring av nye genotyper når noen ble utryddet, et fenomen kjent fra antibakterielle vaksiner, men så langt ikke beskrevet for virus. I studier har man heller ikke sett indikasjoner på dette etter HPVvaksinasjon $(15,16)$.

\section{Bivirkninger}

Det har naturlig nok vært stor oppmerksomhet rundt vurderingen av bivirkninger. Den initiale kunnskapen kom fra de store kliniske utprøvingsprogrammene med vel 30000 deltagere med den kvadrivalente vaksinen og ca. 40000 med den bivalente. Resultatene var helt sammenfallende med klart mer lokal reaksjon på innstikkstedet, litt mer feberreaksjon, men ellers ikke økt risiko for noen andre bivirkninger $(2,17)$.

Langtidsoppfølging av deltagerne i mer enn ti år har ikke endret dette bildet. Sjeldne sykdommer og syndromer kan ikke forventes å bli adekvat studert, selv i så store studier som her forelå. Derfor har det vært foretatt flere studier av insidens før og etter vaksinestart (18). I en viktig studie fra Danmark og Sverige ble 53 sjeldne sykdommer studert hos 300000 vaksinerte og 700000 uvaksinerte. Studien viste ingen holdepunkter for overhyppighet av noen av tilstandene (19). Nå er ca. 200 millioner doser distribuert, og den gode sikkerhetsprofilen ble nylig understreket av europeiske myndigheter $(18,20)$.

Det er på sin plass å minne om vaksineprogrammenes sårbarhet, slik vi så det med autismefrykt etter Wakefield-skandalen. En udokumentert påstand om økt risiko for det sjeldne posturalt ortostatisk takykardi-syndromet (POTS) skjøt fart i danske medier og har fått svære konsekvenser i Danmark, med en reduksjon i vaksinedekningen fra nesten $90 \%$ til vel $20 \%$. Nabolandene Norge og Sverige har så langt ikke opplevd dette.

\section{I dag og i morgen}

Vi har i dag tre tilgjengelige HPV-vaksiner: bivalent (HPV-16 og -18), kvadrivalent (HPV-6, -11, -16 og -18) og nivalent (HPV$6,-11,-16,-18,-31,-33,-45,-52$ og -58$)$. Alle består av rent fremstilt kapsidprotein som danner et viruslikt tomt skall, produsert med samme molekylærbiologiske metoder. I en gjennomvaksinert populasjon med nivalent vaksine fremgår det at cervixcancer forventes redusert med $90 \%$ (21). Da kan man diskutere om dagens screeningprogram til en kostnad på ca. 1000 millioner kroner årlig kan skrinlegges fordi sykdommen blir for sjelden.

Enda viktigere kan frigjøringen av knappe helseressurser bli. Tenk bare på presset på patologifaget som en konsekvens 
av spesialanalyser for å ta i bruk kostbare, nye kreftmedikamenter. Morgendagens forenklede program kan bestå av en HPV-test ved ca. 30- og 40-årsalderen. Testene kan tas hjemme og sendes i posten til analyse. Bare de HPV-positive (6-7\%) kan tilbys oppfølging. Her ligger det muligheter for betydelig forenkling og forbedring.

Konklusjonen er fortsatt at nytten av HPVvaksinasjon med god margin er større enn ulempene $(18,20)$.

\section{Ole-Erik Iversen}

oeiv@haukeland.no

Ole-Erik Iversen (f. 1945) er professor emeritus og overlege. Han har siden 2000 deltatt i klinisk utprøving av HPV-vaksiner og epidemiologiske HPV-studier. Han har mangeårige verv innen forebygging av livmorhalskreft.

Forfatter har fylt ut ICMJE-skjemaet og oppgir følgende interessekonflikter: Han har mottatt honorar fra MSD/Merck og GSK i løpet av studiene. Han har også mottatt honorar for foredrag fra SPMSD.

\section{Litteratur}

1. U.S. Food \& Drug Administration. Approval letter human papillomavirus quadrivalent (types 6, 11

16,18 ) vaccine, recombinant $h$ ttp://fda.gov/

BiologicsBloodVaccines/Vaccines/

ApprovedProducts/ucm111283.htm (17.2.2017).
2. FUTURE II Study Group. Quadrivalent vaccine against human papillomavirus to prevent high-grad cervical lesions. N Engl J Med 2007; 356: 1915-27.

3. Haug C. Drømmevaksine eller fortsatt en drøm? Tidsskr Nor Lægeforen 2007: 127: 1331.

4. Haug C. HPV-vaksinen - fortsatt viktige ubesvarte spørsmål. Tidsskr Nor Lægeforen 2007; 127: 1625.

5. Haug C. Høyt henger de ... Tidsskr Nor Legeforen 2008; 128: 2689

6. Bioteknologinemda får vaksine-refs. VG 18.3.2009. http://vg.no/forbruker/helse/helse-og-medisin/ bioteknologinemnda-faar-vaksine-refs/a/541581/ (17.2.2017).

7. Kunnskapssenteret. HPV-vaksinasjon mot livmorhalskreft kan lønne seg.

http://www.kunnskapssenteret.no/nyheter/ hpv-vaksinasjon-mot-livmorhalskreft-kan-lonneseg (17.2.2017).

8. Iversen OE, Miranda MJ, Ulied A et al. Immunogenicity of the 9-valent HPV vaccine using 2-dose regimens in girls and boys vs a 3 -dose regimen in women. JAMA 2016; 316: 2411-21.

9. Iversen $\mathrm{OE}, \mathrm{Moi} \mathrm{H}$. Gi guttene jentevaksinen! Kronikk. Dagens Næringsliv 17.12.2011.

10. McCredie MR, Sharples KJ, Paul C et al. Natural history of cervical neoplasia and risk of invasive cancer in women with cervical intraepithelial neoplasia 3: a retrospective cohort study. Lancet Oncol 2008; 9: 425-34

11. Pagliusi SR, Teresa Aguado M. Efficacy and other milestones for human papillomavirus vaccine introduction. Vaccine 2004; 23: 569-78.

12. Muñoz N, Manalastas R Jr. Pitisuttithum P et al. Safety, immunogenicity, and efficacy of quadrivalent human papillomavirus (types $6,11,16,18$ ) recombinant vaccine in women aged $24-45$ years: a randomised, double-blind trial. Lancet 2009 373: 1949-57.

13. Grein IH, Groot N, Lacerda Ml et al. HPV infection and vaccination in Systemic Lupus Erythematosus patients: what we really should know. Pediatr Rheumatol Online J 2016: 14: 12

14. Tan HH, Goh CL. Viral infections affecting the skin in organ transplant recipients: epidemiology and current management strategies. Am J Clin Dermatol 2006: 7: 13-29.

15. Drolet M, Bénard É, Boily MC et al. Populationlevel impact and herd effects following human papillomavirus vaccination programmes: a systematic review and meta-analysis. Lancet Infect Dis 2015; 15: 565-80

16. Tota JE, Struyf F, Merikukka M et al. Evaluation of type replacement following HPV16/18 vaccination: pooled analysis of two randomized trials. J Natl Cancer Inst 2017; 109: djw300.

17. Paavonen J, Jenkins D, Bosch FX et al. Efficacy of a prophylactic adjuvanted bivalent L1 virus-likeparticle vaccine against infection with human papillomavirus types 16 and 18 in young women: an interim analysis of a phase III double-blind, randomised controlled trial. Lancet 2007; 369: 2161-70.

18. EMA. Human papillomavirus vaccines review. Oppdatert januar 2016. www.ema.europa.eu/ema/ index.jsp?curlpages/medicines/human/referrals/ Human_papillomavirus_vaccines/human (20.12.2016).

19. Arnheim-Dahlström L, Pasternak B, Svanström H et al. Autoimmune, neurological, and venous thromboembolic adverse events after immunisation of adolescent girls with quadrivalent human papillomavirus vaccine in Denmark and Sweden: cohort study. BMJ 2013; 347: f5906.

20. Wathion N. HPV-vaksiner er trygge å bruke. Tidsskr Nor Legeforen 2017; 137: 13-4.

21. Joura EA, Giuliano AR, Iversen OE et al. A 9-valen $H P V$ vaccine against infection and intraepithelial neoplasia in women. N Engl J Med 2015; 372: $711-23$.

Mottatt 25.1. 2017, første revisjon innsendt 14.2. 2017, godkjent 17.2. 2017. Redaktør: Kaveh Rashidi.

Publisert først på nett. 